Pacific Journal of Mathematic 


\title{
APOSYNDETIC PROPERTIES OF UNICOHERENT CONTINUA
}

\author{
DONALD E. BenNeTt
}

In the first part of this paper the structure of $n$-aposyndetic continua is studied. In particular, those continua which are $n$-aposyndetic but fail to be $(n+1)$-aposyndetic are investigated. Unicoherence is shown to be a sufficient condition for an $n$-aposyndetic continuum to be $(n+1)$-aposyndetic. In the final portion of the paper a stronger form of unicoherence is defined. As a point-wise property, aposyndesis and connected im kleinen are shown to be equivalent in continua with this property.

Throughout this paper a continuum is a compact connected metric space and $M$ will denote a continuum. If $N$ is a subcontinuum of $M$, the interior of $N$ in $M$ will be denoted by int $N$. Suppose $p \in M$ and $F$ is a closed subset of $M$ such that $p \notin F . \quad M$ is aposyndetic at $p$ with respect to $F$ if there is a subcontinuum $N$ of $M$ such that $p \in \operatorname{int} N \subset N \subset M-F$. Let $n$ be a positive integer. If $M$ is aposyndetic at $p$ with respect to each subset of $M$ consisting of $n$ points, then $M$ is $n$-aposyndetic at $p . \quad M$ is n-aposyndetic if it is $n$-aposyndetic at each point. By convention if $M$ is 1-aposyndetic then $M$ is said to be aposyndetic.

For other terms not defined herein, see [3], [4] and [6].

Lemma 1. Suppose $M$ is n-aposyndetic, $p \in M, F$ is a subset of $M-\{p\}$ consisting of $n+1$ points, and $M$ is not aposyndetic at $p$ with respect to $F$. If $F_{1}$ and $F_{2}$ are disjoint nonempty subsets of $F$ such that $F=F_{1} \cup F_{2}$, there exist subcontinua $H$ and $K$ such that $F_{1} \subset H-K$, $F_{2} \subset K-H, p \in \operatorname{int}(H \cap K)$, and $M=H \cup K$.

Proof. Suppose $F_{1}$ and $F_{2}$ are disjoint nonempty subsets of $F$ and $F=F_{1} \cup F_{2}$. For each $x \in F_{1}$ there is a subcontinuum $N_{x}$ in $M-$ $(F-\{x\})$ such that $p \in \operatorname{int} N_{x}$. Clearly $x \in N_{x}$. Let $A=\bigcup\left\{N_{x}: x \in F_{1}\right\}$. For each $x \in F_{1}$ there is a subcontinuum $L_{x}$ such that $x \in \operatorname{int} L_{x}$ and $L_{x} \cap F_{2}=\varnothing$. Let $A_{1}=A \cup\left(\cup\left\{L_{x}: x \in F_{1}\right\}\right)$. Then $A_{1}$ is a continuum, $\{p\} \cup F_{1} \subset \operatorname{int} A_{1}$, and $A_{1} \cap F_{2}=\varnothing$.

Now by interchanging the roles of $F_{1}$ and $F_{2}$ we obtain a continuum $A_{2}$ such that $\{p\} \cup F_{2} \subset \operatorname{int} A_{2}$ and $A_{2} \cap F_{1}=\varnothing$.

Let $V=\left(M-A_{1}\right) \cap \operatorname{int} A_{2}$ and $U=\left(M-A_{2}\right) \cap \operatorname{int} A_{1}$. Let $H$ be the component of $M-V$ which contains $A_{1}$ and let $K$ be the component of $M-U$ which contains $A_{2}$. Then $F_{1} \subset H-K, F_{2} \subset K-H$, 
$p \in \operatorname{int}(H \cap K)$, and $M=H \cup K$.

Theorem 1. Suppose $M$ is n-aposyndetic but fails to be $(n+1)$ aposyndetic. Then for each pair of positive integers $i$ and $j$ such that $i+j=n+1$, there exist subcontinua $H$ and $K$ such that $H$ is not $i$-aposyndetic, $K$ is not $j$-aposyndetic, and $M=H \cup K$.

Proof. Suppose $M$ is not aposyndetic at $p$ with respect to $F=$ $\left\{x_{1}, x_{2}, \cdots, x_{n}, x_{n+1}\right\}$. Let $i$ and $j$ be positive integers such that $i+j=$ $n+1$. Let $F_{i}=\left\{x_{1}, x_{2}, \cdots, x_{i}\right\}$ and $F_{j}=\left\{x_{i+1}, x_{i+2}, \cdots, x_{n+1}\right\} . \quad$ By Lemma 1 there are subcontinua $H$ and $K$ such that $F_{i} \subset H-K$, $F_{j} \subset K-H, p \in \operatorname{int}(H \cap K)$, and $M=H \cup K$.

Now if $H$ is $i$-aposyndetic, there is a subcontinuum $N$ in $H-F_{i}$ and a set $V$ open in $H$ such that $p \in V \subset N$. Let $U=(\operatorname{int}(H \cap K)) \cap V$. Then $U$ is open in $M$ and $p \in U \subset N \subset M-F$. Since this is contrary to the supposition, $H$ is not $i$-aposyndetic.

In a similar manner, it follows that $K$ fails to be $j$-aposyndetic.

Theorem 2. Let $n$ be a positive integer and suppose $M$ is $n$ aposyndetic. If $M$ is unicoherent, then $M$ is $(n+1)$-aposyndetic.

Proof. Suppose $M$ fails to be $(n+1)$-aposyndetic. There is a $p \in M$, a set $F=\left\{x_{0}, x_{1}, \cdots, x_{n}\right\}$ consisting of $n+1$ points in $M-\{p\}$, and $M$ is not aposyndetic at $p$ with respect to $F$. By Lemma 1 , there are continua $H$ and $K$ such that $\left\{x_{0}\right\} \subset H-K,\left\{x_{1}, x_{2}, \cdots, x_{n}\right\} \subset$ $K-H, p \in \operatorname{int}(H \cap K)$, and $M=H \cup K$. Since $p \in \operatorname{int}(H \cap K) \subset H \cap$ $K \subset M-F$, it follows that $H \cap K$ is not a continuum. Therefore $M$ fails to be unicoherent.

CoRollary 1. Suppose $M$ is unicoherent and aposyndetic. Then for each positive integer $n, M$ is n-aposyndetic.

A continuum $M$ is said to be $k$-coherent (finitely coherent) provided that for each pair of proper subcontinua $H$ and $K$ such that $M=H \cup K$, then $H \cap K$ has at most $k$ components (a finite number of components). Thus unicoherence is the same as 1-coherence.

With obvious modifications, Theorem 2 and Corollary 1 also hold for continua which are finitely coherent.

In [5] Vought proves that a planar continuum is locally connected if and only if it is 2-aposyndetic. By combining this result with Corollary 1 we have the following theorem.

THeOREM 3. Let $M$ be unicoherent planar continuum. Then $M$ is locally connected if and only if $M$ is aposyndetic. 
The following example shows that the theorem does not hold if $M$ fails to be planar.

EXAMPLE 1. Let $M$ be the product of the cone over the Cantor set with the unit interval. Then $M$ is unicoherent and aposyndetic but is not locally connected.

According to [1, Th. 13, p. 100] and [3, Th. 2, p. 437], each planar continuum which fails to separate the plane is unicoherent. Thus the following theorem is an immediate consequence of Theorem 3.

THEOREM 4. (Jones [2]) Suppose $M$ is a planar continuum which does not separate the plane. Then $M$ is locally connected if and only if $M$ is aposyndetic.

A dendrite is a locally connected continuum which does not contain a simple closed curve. One of many characterizations of a dendrite is that a continuum is a dendrite if and only if it is one-dimensional, unicoherent, and locally connected [3, Cor. 8, p. 442].

Question. If $M$ is a one-dimensional, unicoherent, aposyndetic continuum, does it follow that $M$ is a dendrite?

It is easily seen that if $M$ is hereditarily unicoherent and aposyndetic, then $M$ is locally connected and hence a dendrite. The following results establish a weaker condition under which aposyndesis and locally connectedness are equivalent.

Definition. A decomposable unicoherent continuum $M$ is strongly unicoherent provided that for each pair of proper subcontinua $H$ and $K$ such that $M=H \cup K$, both $H$ and $K$ are unicoherent.

ExAmple 2. Let $M$ consist of a ray $R$ and a simple closed curve $C$ such that $R$ limits on $C$. Clearly $M$ is strongly unicoherent, but not hereditarily unicoherent since it contains the non-unicoherent continuum $C$.

THEOREM 5. Suppose $M$ is strongly unicoherent and aposyndetic. Then $M$ is hereditarily decomposable.

Proof. Let $N$ be a proper subcontinuum of $M$ and let $x$ and $y$ be distinct points of $N$. Since $M$ is aposyndetic, there exist subcontinua $H$ and $K$ such that $x \in H-K, y \in K-H$, and $M=H \cup K$ [2]. Now $H \cup N$ and $K \cup N$ are subcontinua of $M$ and $(H \cup N) \cup K=M=$ 
$H \cup(K \cup N)$. It follows that $H \cap N$ and $K \cap N$ are nonempty continua and $N=(H \cap N) \cup(K \cap N)$. Thus $N$ is decomposable.

COROLlaRy 2. A strongly unicoherent aposyndetic continuum is one-dimensional.

THEOREM 6. Suppose $M$ is strongly unicoherent. Then $M$ is aposyndetic at a point $p$ if and only if $M$ is connected im kleinen at $p$.

Proof. If $M$ is connected im kleinen at $p$, it is immediate that $M$ is aposyndetic at $p$.

Suppose $M$ is aposyndetic at $p$ and is not connected im kleinen at $p$. There is an open set $U$ containing $p$ such that $M$ is not aposyndetic at $p$ with respect to $M-U$. This property on " $p$ " is inducible. Thus by the Brower Reduction Theorem [6, Th. 11, p. 17], there is an open set $V$ such that $U \subset V, M$ is not aposyndetic at $p$ with respect to $M-V$, but for any open set $W$ properly containing $V, M$ is aposyndetic at $p$ with respect to $M-W$.

Let $x \in M-V$. There is a subcontinuum $N$ in $M-\{x\}$ such that $p \in \operatorname{int} N$.

Assertion. There are proper subcontinua $H$ and $K$ such that $M=H \cup K, p \in \operatorname{int} H$, and $x \in K-H$. For if $N$ does not separate $M$, let $H=N$ and $K=\mathrm{Cl}(M-N)$. If $N$ separates $M$ into disjoint open sets $S$ and $T$, assume $x \in T$; let $H=N \cup S$, and let $K=N \cup T$.

Let $A=(M-V) \cap H$. If $A=\varnothing$, then $M-V \subset K-H$ which implies that $M$ is aposyndetic at $p$ with respect to $M-V$. So assume $A \neq \varnothing$. Since $M-A$ properly contains $V$, there is a subcontinuum $L$ in $M-A$ such that $p \in \operatorname{int} L$. Now $p \in[(\operatorname{int} H) \cap(\operatorname{int} L)] \subset L \cap H \subset V$ which implies that $L \cap H$ is not a continuum. Since $M=(L \cup H) \cup K$, this contradicts the strong unicoherence of $M$.

Therefore $M$ is connected im kleinen at $p$.

CoRollary 3. Suppose $M$ is strongly unicoherent. Then $M$ is aposyndetic if and only if $M$ is locally connected.

Since a strongly unicoherent aposyndetic continuum is one-dimensional (Corollary 2), we have the following characterization of a dendrite.

Theorem 7. A continuum $M$ is a dendrite if and only if $M$ is strongly unicoherent and aposyndetic. 
If the answer to the question proposed above is negative, then the following corollary provides some information concerning the structure of such continua.

Corollary 4. Let $M$ be a unicoherent, aposyndetic, one-dimensional continuum. If $M$ is not a dendrite, there exist proper subcontinua $H$ and $K$ such that $M=H \cup K$ and either $H$ or $K$ fails to be unicoherent.

\section{REFERENCES}

1. W. Hurewicz and H. Wallman, Dimension Theory, Princeton U. Press, 1948, Princeton, N. J.

2. F. B. Jones, Aposyndetic continua and certain boundary problems, Amer. J. Math., 63 (1941), 545-553.

3. K. Kuratowski, Topology II, Academic Press, 1968, New York and London.

4. R. L. Moore, Foundations of point set theory, Amer. Math. Soc., Colloquium Publications, Vol. 13, Revised Edition, 1962, New York.

5. E. J. Vought, n-Aposyndetic continua and cutting theorems, Trans. Amer. Math. Soc., 140 (1969), 127-135.

6. G. T. Whyburn, Analytical Topology, Amer. Math. Soc., Colloquium Publications, Vol. 28, 1942, New York.

Received September 21, 1970. This paper is part of the author's dissertation written under the direction of Professor J. B. Fugate at the University of Kentucky. The author wishes to express his appreciation to Professor Fugate for his guidance and encouragement.

UNIVERSITY OF KENTUCKY

LEXINGTON, KENTUCKY

AND

MURRay State University

MURRAY, KENTUCKY 



\title{
PACIFIC JOURNAL OF MATHEMATICS
}

\author{
EDITORS
}

\author{
H. SAMelson \\ Stanford University \\ Stanford, California 94305 \\ C. R. HoBBy \\ University of Washington \\ Seattle, Washington 98105
}

J. DugunduI

Department of Mathematics

University of Southern California

Los Angeles, California 90007

RICHARD ARENS

University of California

Los Angeles, California 90024

\section{ASSOCIATE EDITORS}

\author{
E. F. BeCKENBACH
}

B. H. NEUMANN

F. WoLF

K. YOSHIDA

\section{SUPPORTING INSTITUTIONS}

\author{
UNIVERSITY OF BRITISH COLUMBIA \\ CALIFORNIA INSTITUTE OF TECHNOLOGY \\ UNIVERSITY OF CALIFORNIA \\ MONTANA STATE UNIVERSITY \\ UNIVERSITY OF NEVADA \\ NEW MEXICO STATE UNIVERSITY \\ OREGON STATE UNIVERSITY \\ UNIVERSITY OF OREGON \\ OSAKA UNIVERSITY \\ UNIVERSITY OF SOUTHERN CALIFORNIA
}

\author{
STANFORD UNIVERSITY \\ UNIVERSITY OF TOKYO \\ UNIVERSITY OF UTAH \\ WASHINGTON STATE UNIVERSITY \\ UNIVERSITY OF WASHINGTON \\ AMERICAN MATHEMATICAL SOCIETY \\ CHEVRON RESEARCH CORPORATION \\ NAVAL WEAPONS CENTER
}

The Supporting Institutions listed above contribute to the cost of publication of this Journal, but they are not owners or publishers and have no responsibility for its content or policies.

Mathematical papers intended for publication in the Pacific Journal of Mathematics should be in typed form or offset-reproduced, (not dittoed), double spaced with large margins. Underline Greek letters in red, German in green, and script in blue. The first paragraph or two must be capable of being used separately as a synopsis of the entire paper. The editorial "we" must not be used in the synopsis, and items of the bibliography should not be cited there unless absolutely necessary, in which case they must be identified by author and Journal, rather than by item number. Manuscripts, in duplicate if possible, may be sent to any one of the four editors. Please classify according to the scheme of Math. Rev. Index to Vol. 39. All other communications to the editors should be addressed to the managing editor, Richard Arens, University of California, Los Angeles, California, 90024.

50 reprints are provided free for each article; additional copies may be obtained at cost in multiples of 50 .

The Pacific Journal of Mathematics is published monthly. Effective with Volume 16 the price per volume (3 numbers) is $\$ 8.00$; single issues, $\$ 3.00$. Special price for current issues to individual faculty members of supporting institutions and to individual members of the American Mathematical Society: $\$ 4.00$ per volume; single issues $\$ 1.50$. Back numbers are available.

Subscriptions, orders for back numbers, and changes of address should be sent to Pacific Journal of Mathematics, 103 Highland Boulevard, Berkeley, California, 94708.

PUBLISHED BY PACIFIC JOURNAL OF MATHEMATICS, A NON-PROFIT CORPORATION

Printed at Kokusai Bunken Insatsusha (International Academic Printing Co., Ltd.), 7-17, Fujimi 2-chome, Chiyoda-ku, Tokyo, Japan. 


\section{Pacific Journal of Mathematics}

\section{Vol. 37, No. $3 \quad$ March, 1971}

Mohammad Shafqat Ali and Marvin David Marcus, On the degree of the

minimal polynomial of a commutator operator ................ 561

Howard Anton and William J. Pervin, Integration on topological

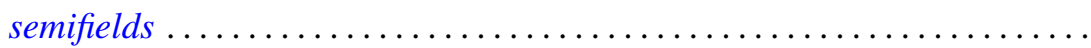

Martin Bartelt, Multipliers and operator algebras on bounded analytic

functions .................................... 575

Donald Earl Bennett, Aposyndetic properties of unicoherent continua ...... 585

James W. Bond, Lie algebras of genus one and genus two ............. 591

Mario Borelli, The cohomology of divisorial varieties ............... 617

Carlos R. Borges, How to recognize homeomorphisms and isometries ....... 625

J. C. Breckenridge, Burkill-Cesari integrals of quasi additive interval

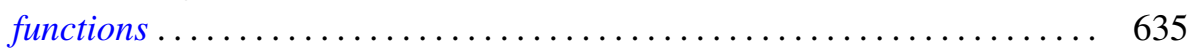

J. Csima, A class of counterexamples on permanents ................ 655

Carl Hanson Fitzgerald, Conformal mappings onto $\omega$-swirly domains . . . . . . 657

Newcomb Greenleaf, Analytic sheaves on Klein surfaces .............. 671

G. Goss and Giovanni Viglino, C-compact and functionally compact

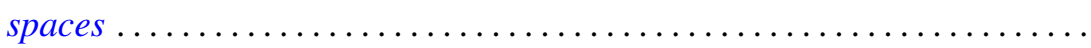

Charles Lemuel Hagopian, Arcwise connectivity of semi-aposyndetic plane

continua ..................................... 683

John Harris and Olga Higgins, Prime generators with parabolic limits ...

David Michael Henry, Stratifiable spaces, semi-stratifiable spaces, and their

relation through mappings .......................

Raymond D. Holmes, On contractive semigroups of mappings ........... 701

Joseph Edmund Kist and P. H. Maserick, BV-functions on semilattices ....... 711

Shûichirô Maeda, On point-free parallelism and Wilcox lattices ........... 725

Gary L. Musser, Linear semiprime $(p ; q)$ radicals ................. 749

William Charles Nemitz and Thomas Paul Whaley, Varieties of implicative

semilattices..................................... 759

Jaroslav Nešetřil, A congruence theorem for asymmetric trees ............ 771

Robert Anthony Nowlan, A study of $H$-spaces via left translations .......... 779

Gert Kjærgaard Pedersen, Atomic and diffuse functionals on a $C^{*}$-algebra ... 795

Tilak Raj Prabhakar, On the other set of the biorthogonal polynomials

suggested by the Laguerre polynomials...

801

Leland Edward Rogers, Mutually aposyndetic products of chainable

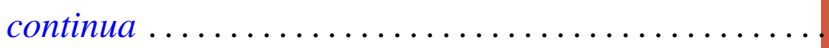

Frederick Stern, An estimate for Wiener integrals connected with squared

error in a Fourier series approximation.

Leonard Paul Sternbach, On k-shrinking and k-boundedly complete basic

sequences and quasi-reflexive spaces .................... 817

Pak-Ken Wong, Modular annihilator $A^{*}$-algebras ........ 